\title{
Laboratory-Scale Investigation of Biogas Treatment by Removal of Hydrogen Sulfide and Carbon Dioxide
}

\author{
Jakub Lasocki ${ }^{\text {* }}$, Krzysztof Kołodziejczyk ${ }^{2}$, Anna Matuszewska ${ }^{3}$ \\ 'Institute of Vehicles, Faculty of Automotive and Construction Machinery Engineering, \\ Warsaw University of Technology, Poland \\ ${ }^{2}$ POLMAX S.A. S.K.A., Department of Research and Development, Świebodzin Branch, Poland \\ ${ }^{3}$ Automotive Industry Institute, Department of Fuels, Biofuels and Lubricants, Poland
}

Received: 18 November 2014

Accepted: 11 January 2015

\begin{abstract}
The use of organic residues and waste for production of biogas as an energy source is a viable option for waste management and reduction of greenhouse gas emissions. However, before any eventual utilization of biogas, hydrogen sulfide $\left(\mathrm{H}_{2} \mathrm{~S}\right)$ and carbon dioxide $\left(\mathrm{CO}_{2}\right)$ must be removed since those contaminants are highly undesirable in combustion systems. This work deals with the construction and examination of a laboratoryscale, low-cost test stand for quick evaluation of the existing and new methods for $\mathrm{H}_{2} \mathrm{~S}$ and $\mathrm{CO}_{2}$ removal from biogas. The test stand consists of two sections: one based on absorption in liquid phase (barbotage process) and the other adsorption in a bed of solid reagent. Seven different reagents of various concentrations were used in the experiment: sodium hydroxide $(\mathrm{NaOH})$, ethylene glycol $(\mathrm{EG})$, ethanoloamine (EA), diethanoloamine (DEA), and distilled water $\left(\mathrm{H}_{2} \mathrm{O}\right)$ in the barbotage section of the test stand, and bog iron ore (BIO) and activated carbon $(\mathrm{AC})$ in the adsorption column. In the absorption tests, treating biogas with $1 \mathrm{M} \mathrm{NaOH}$ solution and $100 \%$ EA resulted in complete removal of $\mathrm{H}_{2} \mathrm{~S}$ and $\mathrm{CO}_{2}$. For $100 \%$ DEA, high $\mathrm{H}_{2} \mathrm{~S}$ and moderate $\mathrm{CO}_{2}$ absorption efficiency were achieved. $\mathrm{EG}$ and $\mathrm{H}_{2} \mathrm{O}$ allowed the removal of $\mathrm{H}_{2} \mathrm{~S}$ only to a very limited extent. Both reagents used in the tests with adsorption in a bed, $\mathrm{BIO}$ and $\mathrm{AC}$, were able to eliminate $\mathrm{H}_{2} \mathrm{~S}$ from biogas, but practically did not change the concentration of $\mathrm{CO}_{2}$.
\end{abstract}

Keywords: renewable energy sources, biomethane, biogas upgrading, laboratory-scale, chemical absorption

\section{Introduction}

The negative environmental and health effects of building the world economy based on fossil fuels have triggered global interest in the search for clean sources of energy [1, 2]. One of the most promising ways to fulfill those needs is the use of various biofuels $[1,3,4]$. However, while it is desirable to reduce the use of non-renewable energy

*e-mail: j.lasocki@simr.pw.edu.pl sources, some biofuels may have even higher impact on environmental degradation than fossil fuels when considering the whole production process, including plant cultivation [5-7]. Compared to biodiesel and bioethanol (already widely used in the transportation sector in many countries), biogas production from organic residues and waste offers not only a significant reduction in greenhouse gas emissions [8], but it can also be regarded as an effective method of waste management $[9,10]$. Biogas can be perceived as a flexible and inexhaustible source of energy [11] with the 
Table 1. Overview of the main compositions of biogas from different sources [15].

\begin{tabular}{|l|c|c|c|}
\hline Component & Biogas factory & Sewer factory & Garbage landfill \\
\hline $\mathrm{CH}_{4}[\%]$ & $60-70$ & $55-65$ & $45-55$ \\
\hline $\mathrm{CO}_{2}[\%]$ & $30-40$ & $35-45$ & $30-40$ \\
\hline $\mathrm{N}_{2}[\%]$ & $<1$ & $<1$ & $5-15$ \\
\hline $\mathrm{H}_{2} \mathrm{~S}[\mathrm{ppm}]$ & $10-2000$ & $10-40$ & $50-300$ \\
\hline
\end{tabular}

potential to ensure energy security through diversification of energy sources and thus providing independence from external political factors $[1,2]$.

The chemical composition of raw biogas (Table 1) depends strongly on the kinds of substrates used. Biogas consists of two main components: methane $\left(\mathrm{CH}_{4}\right)$ and carbon dioxide $\left(\mathrm{CO}_{2}\right)$. Trace quantities of other substances are often present in biogas e.g.: hydrogen sulfide $\left(\mathrm{H}_{2} \mathrm{~S}\right)$, ammonia $\left(\mathrm{NH}_{3}\right)$, halogenated volatile organic compounds (VOCs), siloxanes, carbon monoxide (CO), oxygen $\left(\mathrm{O}_{2}\right)$, and water $\left(\mathrm{H}_{2} \mathrm{O}\right)$ [12]. Among all the biogas components other than methane, $\mathrm{CO}_{2}$ and $\mathrm{H}_{2} \mathrm{~S}$ are highly undesirable in combustion systems [13]. $\mathrm{CO}_{2}$, the non-combustible compound, decreases the calorific value of the biogas but, on the other hand, is not toxic. In contrast, $\mathrm{H}_{2} \mathrm{~S}$ is poisonous when inhaled. Moreover, a high concentration of $\mathrm{H}_{2} \mathrm{~S}$ causes corrosion of the metallic parts of compressors, gas storage tanks, and engines, especially when water is present in biogas, resulting in extra costs of infrastructure maintenance $[12,14]$. The removal of those contaminants is essential before any eventual utilization of biogas.

The typical biogas treatment process consists of two general steps [12]:

1. Cleaning, in which the harmful (i.e. corrosive and toxic) trace components are removed

2. Upgrading, in which $\mathrm{CO}_{2}$ content is regulated to adjust the calorific value and energetic density of the biogas to an optimal level

The final product of biogas treatment (often referred to as "biomethane") contains about $95-97 \% \mathrm{CH}_{4}$ and $1-3 \%$ $\mathrm{CO}_{2}$, and is practically $\mathrm{H}_{2} \mathrm{~S}$-free [12].

Several techniques for biogas treatment have been developed in recent years. The main differences between them relate to the nature of the operation (i.e. chemical, physical, and biological), operational conditions, efficiency, complexity of the involved infrastructure, investment and maintenance costs, etc. An overview of the currently available and used methods for $\mathrm{H}_{2} \mathrm{~S}$ and $\mathrm{CO}_{2}$ removal, based on Ryckebosch et al. [12], is given in Table 2. Further details, including reaction mechanisms, are widely available in the literature [12-16].

Although certain methods of biogas treatment have been successfully implemented in the industry, their optimization is still needed to achieve the desired efficiency of the process [17]. Furthermore, there is no doubt that new methods will be developed and investigated in the future.
Table 2. Methods used for removal of $\mathrm{H}_{2} \mathrm{~S}$ and $\mathrm{CO}_{2}$ from biogas.

\begin{tabular}{|c|c|}
\hline $\mathrm{H}_{2} \mathrm{~S}$ removal & $\mathrm{CO}_{2}$ removal \\
\hline $\begin{array}{l}\text { Biological treatment by air or } \\
\text { oxygen dosing to the biogas } \\
\text { system in filter, scrubber, or } \\
\text { digester }\end{array}$ & $\begin{array}{c}\text { Pressure swing adsorption } \\
\text { (PSA), vacuum swing adsorp- } \\
\text { tion (VSA) with carbon mole- } \\
\text { cular sieves, zeolites, or alumi- } \\
\text { na silicates }\end{array}$ \\
\hline $\begin{array}{c}\text { Addition of iron chloride } \\
\left(\mathrm{FeCl}_{3}, \mathrm{FeCl}_{2}, \mathrm{FeSO}_{4}\right) \text { into the } \\
\text { digester }\end{array}$ & $\begin{array}{l}\text { Physical absorption with water } \\
\text { or polyethylene glycol }\end{array}$ \\
\hline $\begin{array}{l}\text { Adsorption using iron oxide } \\
\left(\mathrm{Fe}_{2} \mathrm{O}_{3}\right) \text { or iron hydroxide } \\
\left(\mathrm{Fe}(\mathrm{OH})_{3}\right) \text { on a bed formed } \\
\text { from rust steel wool, impreg- } \\
\text { nated wood chips, or pellets }\end{array}$ & $\begin{array}{l}\text { Chemical absorption with } \\
\text { amines: ethanoloamine (EA), } \\
\text { diethanoloamine (DEA), or } \\
\text { diglycoloamine (DGA) }\end{array}$ \\
\hline $\begin{array}{l}\text { Physical absorption with water } \\
\text { or organic solvents }\end{array}$ & $\begin{array}{c}\text { Membrane separation: gas/gas } \\
\text { or gas/liquid }\end{array}$ \\
\hline $\begin{array}{c}\text { Chemical absorption with } \\
\text { solutions of sodium hydroxide } \\
(\mathrm{NaOH}), \mathrm{FeCl}_{2}, \mathrm{Fe}(\mathrm{OH})_{3} \text {, or } \\
\text { ferric complex of EDTA (Fe- } \\
\text { EDTA) }\end{array}$ & Biological removal \\
\hline Membrane separation & Cryogenic separation \\
\hline Biological filter & \\
\hline Adsorption on activated carbon & \\
\hline
\end{tabular}

In order to accelerate these research efforts, laboratoryscale testing apparatus and analytical equipment need to be provided. First of all, simple and low-cost solutions are preferred.

This work deals with the construction and examination of a laboratory-scale test stand for quick evaluation of the technologies for $\mathrm{H}_{2} \mathrm{~S}$ and $\mathrm{CO}_{2}$ removal from biogas. Presented studies had preliminary character, with the emphasis on the analysis of operating conditions of the test stand rather than accurate assessment of reactant efficiency.

\section{Experimental Procedures}

\section{Apparatus}

All experiments were performed with the use of a laboratory-scale test stand for biogas treatment (Fig. 1) developed in the Automotive Industry Institute. The test stand consists of two main sections: one based on absorption in liquid phase (barbotage process) and the other adsorption in a bed of solid reagent. These sections can be connected in two ways: in parallel or in series. Raw biogas is fed from a high-pressure cylinder. Its rate of flow is measured and regulated to a desired value with a Rotametr ROS-06 variable area flowmeter equipped with a flow control valve. After passing through the sections, treated biogas is analyzed with a GasData GFM 416 biogas analyzer and then released into the atmosphere. 


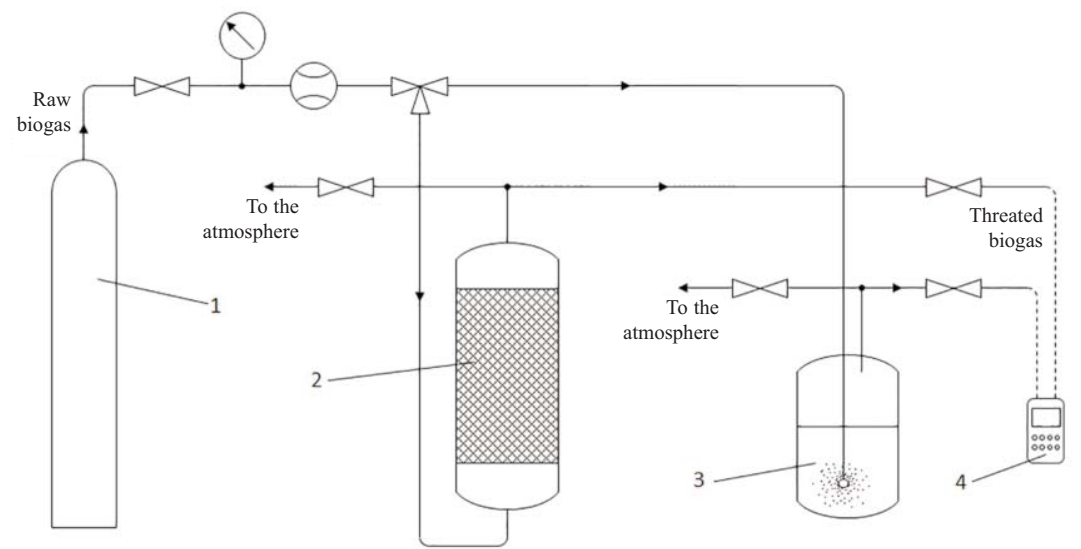

Fig. 1. Flow diagram of laboratory-scale test stand for biogas treatment (parallel connection): 1 - high pressure cylinder with raw biogas, 2 - adsorption in a bed of solid reagent section, 3 - barbotage section, 4 - gas analyzer.

The barbotage section of the biogas treatment test stand is shown in Fig. 2. The glass container of $1 \mathrm{dm}^{3}$ capacity filled with $0.5 \mathrm{dm}^{3}$ of liquid reagent is its key component. The container is sealed with rubber cap and restricting plastic bands to protect it from being opened due to increasing gas pressure. Two openings for biogas transferring tubes (inlet and outlet) are made in the cap. Raw biogas is fed through the inlet tube to the bubbler placed in the liquid reagent, and then, after passing through the liquid, discharged from the system through the outlet tube. A sample of the treated gas is taken and its composition is analyzed.

The section for adsorption in a bed of solid reagent is shown in Fig. 3. Raw biogas is passed through a bed placed in a glass column of $56 \mathrm{~mm}$ diameter and $230 \mathrm{~mm}$ height. The height of the bed can be changed for each test. In order to ensure uniform distribution of biogas throughout the bed, and to prevent the inlet pipe from being clogged up by

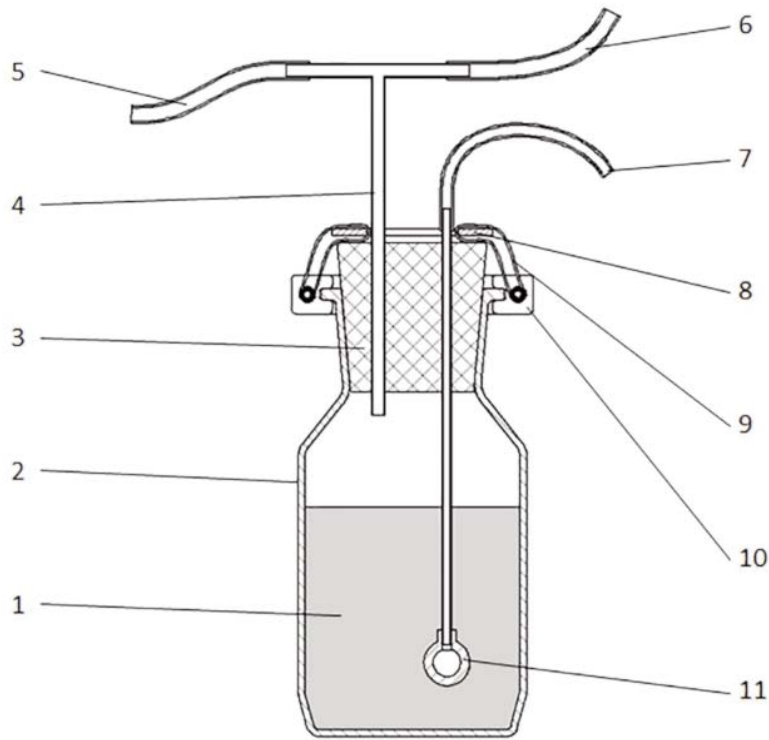

Fig. 2. Barbotage section of the biogas treatment test stand: 1 - liquid reagent, 2 - glass container, 3 - rubber cap, 4 - glass tee-tube, 5 - biogas outlet tube (to gas analyzer), 6 - biogas outlet tube (to the atmosphere), 7 - biogas inlet tube, 8 - steel ring, 9 - restricting plastic band, 10 - flange, 11 - bubbler. adsorbent particles, the bottom of the column is filled with glass beads. Next, treated biogas is passed through a filtration unit made of a glass column with synthetic wool as the filtration material. Finally, it is discharged from the system while the sampling tube takes the sample to the biogas composition analyzer.

The developed test stand allows carrying out a wide range of experiments by connecting each individual section with different configurations. The number of sections of each type applied simultaneously (in parallel or in series) could be varied as required by the experimental procedure.

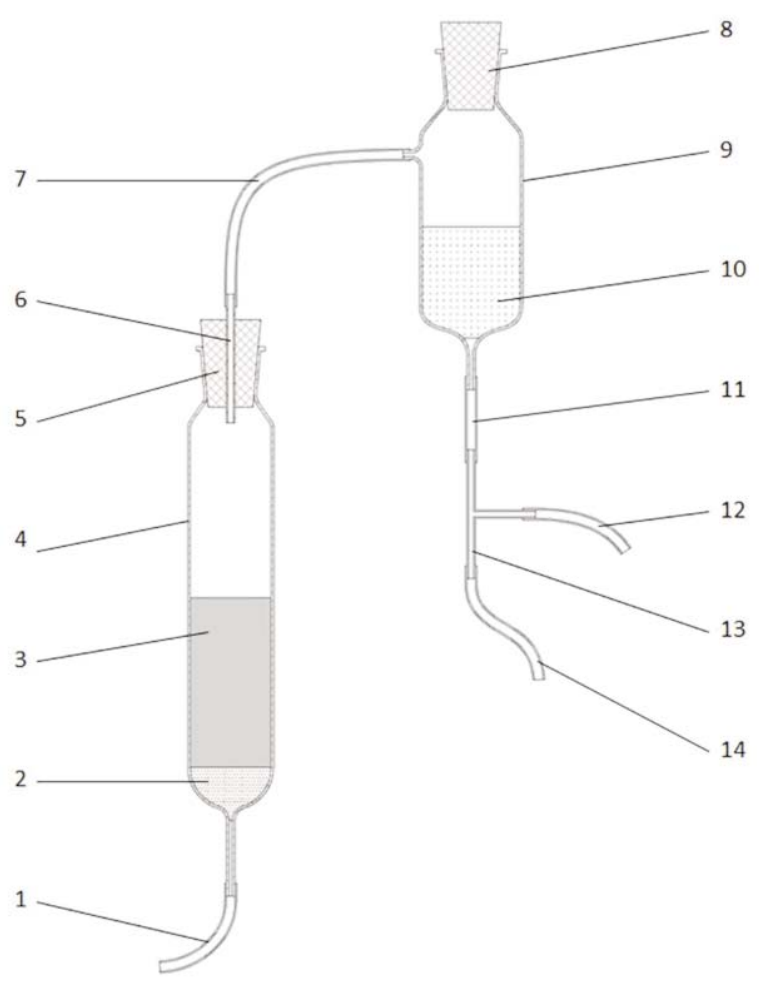

Fig. 3. The section for adsorption in a bed of solid reagent: 1 - biogas inlet tube, 2 - glass beads, 3 - adsorbent bed, 4 - glass column, 5 - rubber cap, 6 - glass pipe, 7 - connecting tube, 8 - rubber cap, 9 - glass column, 10 - filter material, 11 - connecting tube, 12 - biogas outlet tube (to gas analyzer), 13 - glass tee, 14 - biogas outlet tube (to the atmosphere). 
Table 3. Reagents used in the experimental work.

\begin{tabular}{|c|c|c|}
\hline Test stand section & Reagent & Note \\
\hline \multirow{4}{*}{ Barbotage } & Sodium hydroxide (NaOH) & $0.3 \mathrm{M}, 0.5 \mathrm{M}, 1 \mathrm{M}$ aqueous solutions \\
\cline { 2 - 3 } & Ethylene glycol (EG) & $100 \%, 10 \mathrm{M}$ aqueous solution \\
\cline { 2 - 3 } & Ethanoloamine (EA) & $100 \%$ \\
\cline { 2 - 3 } & Diethanoloamine (DEA) & $100 \%$ \\
\cline { 2 - 3 } & Distilled water ( $\left.\mathrm{H}_{2} \mathrm{O}\right)$ & \\
\hline \multirow{3}{*}{$\begin{array}{c}\text { Adsorption in a bed of } \\
\text { solid reagent }\end{array}$} & Bog iron ore (BIO) & Bed height of (reagent mass): $30 \mathrm{~mm}(50 \mathrm{~g}), 53 \mathrm{~mm}(100 \mathrm{~g}), 80 \mathrm{~mm}(150 \mathrm{~g})$ \\
\cline { 2 - 3 } & Activated carbon (AC) & Bed height of (reagent mass): $23 \mathrm{~mm}(25 \mathrm{~g}), 33 \mathrm{~mm}(35 \mathrm{~g}), 43 \mathrm{~mm}(50 \mathrm{~g})$ \\
\hline
\end{tabular}

Table 4. Composition of biogas after 10 min of the barbotage treatment with different solvents.

\begin{tabular}{|l|c|c|c|}
\hline & $\mathrm{CH}_{4}[\%]$ & $\mathrm{CO}_{2}[\%]$ & $\mathrm{H}_{2} \mathrm{~S}[\mathrm{ppm}]$ \\
\hline Inlet & 55.0 & 44.5 & 5000 \\
\hline $0.3 \mathrm{M} \mathrm{NaOH}$ & 95.8 & 4.2 & 0 \\
\hline $0.5 \mathrm{M} \mathrm{NaOH}$ & 99.7 & 0.3 & 0 \\
\hline $1 \mathrm{M} \mathrm{NaOH}$ & 100.0 & 0.0 & 0 \\
\hline $100 \% \mathrm{EG}$ & 55.1 & 44.6 & 2217 \\
\hline $10 \mathrm{M} \mathrm{EG}$ & 53.3 & 46.4 & 2606 \\
\hline EA & 100.0 & 0.0 & 0 \\
\hline $\mathrm{DEA}$ & 84.8 & 15.2 & 0 \\
\hline $\mathrm{H}_{2} \mathrm{O}$ & 54.1 & 45.7 & 2627 \\
\hline
\end{tabular}

Table 5. Composition of biogas after $10 \mathrm{~min}$ of the treatment with adsorption in a bed of solid reagent: $\mathrm{h}$ - bed height

\begin{tabular}{|c|c|c|c|}
\hline & $\mathrm{CH}_{4}[\%]$ & $\mathrm{CO}_{2}[\%]$ & $\mathrm{H}_{2} \mathrm{~S}[\mathrm{ppm}]$ \\
\hline Inlet & 55.0 & 44.5 & 5000 \\
\hline $\mathrm{BIO}, \mathrm{h}=30$ & 52.7 & 47.2 & 430 \\
\hline $\mathrm{BIO}, \mathrm{h}=53$ & 52.6 & 47.3 & 160 \\
\hline $\mathrm{BIO}, \mathrm{h}=80$ & 53.3 & 46.7 & 0 \\
\hline $\mathrm{AC}, \mathrm{h}=23$ & 54.9 & 45.1 & 0 \\
\hline $\mathrm{AC}, \mathrm{h}=33$ & 55.0 & 45.0 & 0 \\
\hline $\mathrm{AC}, \mathrm{h}=43$ & 56.6 & 43.4 & 0 \\
\hline
\end{tabular}

\section{Materials}

Seven different substances were used as chemical reagents to demonstrate the functionality of the experimental apparatus and its ability to absorb $\mathrm{CO}_{2}$ and $\mathrm{H}_{2} \mathrm{~S}$ (Table $3)$.
Biogas received from a biological process has a tendency to stratify in the storage tanks. On that account, to ensure the stable composition of the tested biogas - and therefore the comparability of the results obtained with the use of different methods and different chemical reagents - all experiments were carried out using a reference gas mixture ("synthetic biogas"). The gas mixture consisted of 55\% $\mathrm{CH}_{4}, 44.5 \% \mathrm{CO}_{2}$, and 5,000 ppm $\mathrm{H}_{2} \mathrm{~S}$.

\section{Test Procedure}

In the research work presented in this paper, each section of the biogas treatment test stand (barbotage, adsorption in a bed of solid reagent) was examined separately, i.e. the biogas was not passed through both sections at the same time. The single-stage test procedure involved passing the biogas through one of the sections for $30 \mathrm{~min}$. Every $5 \mathrm{~min}$ the composition of treated biogas was analyzed by measuring the concentrations of $\mathrm{CH}_{4}, \mathrm{CO}_{2}$, and $\mathrm{H}_{2} \mathrm{~S}$ at the outlet stream. Tests were performed at room temperature. Biogas flow was set at $20 \mathrm{dm}^{3} / \mathrm{h}$.

\section{Results and Discussion}

\section{Biogas Treatment Using Absorption with Barbotage}

Composition of biogas downstream of the barbotage section after $10 \mathrm{~min}$ of operation is shown in Table 4. It was observed that both $\mathrm{NaOH}$ and EA reagents removed comparatively high levels of $\mathrm{H}_{2} \mathrm{~S}$ and $\mathrm{CO}_{2}$, resulting in $\mathrm{CH}_{4}$ enriched biogas. DEA completely absorbed $\mathrm{H}_{2} \mathrm{~S}$ and partially $\mathrm{CO}_{2}$. EG and $\mathrm{H}_{2} \mathrm{O}$ reduced $\mathrm{H}_{2} \mathrm{~S}$ concentration at the outlet stream by half, but failed to remove $\mathrm{CO}_{2}$. However, the process was time-dependent as gaseous concentrations of $\mathrm{H}_{2} \mathrm{~S}$ and $\mathrm{CO}_{2}$ started to evolve in the outlet stream after a certain time (Fig. 4). In most cases, at the beginning of the process liquid solvents reacted rapidly and the concentrations of $\mathrm{H}_{2} \mathrm{~S}$ and $\mathrm{CO}_{2}$ in the outlet streams were significantly lower than in the inlet streams. As the absorption 
process proceeded with time, $\mathrm{H}_{2} \mathrm{~S}$ and $\mathrm{CO}_{2}$ continuously accumulated in the solvents and their concentrations in the outlet stream eventually increased. The saturation/neutralization points of the solvents were not determined. The observed trends were not distinct for $\mathrm{CO}_{2}$ absorption with EG and DEA (rather stable concentration levels) as well as for $\mathrm{H}_{2} \mathrm{~S}$ absorption with EA, DEA, and highly concentrated $\mathrm{NaOH}$ (almost complete absorption).

\section{Biogas Treatment Using Adsorption in a Bed of Solid Reagent}

Table 5 shows the effects of biogas treatment using adsorption in beds of BIO and AC after 10 min of operation. The results indicated high removal efficiency of both substances (in particular AC) towards $\mathrm{H}_{2} \mathrm{~S}$ and poor

a)

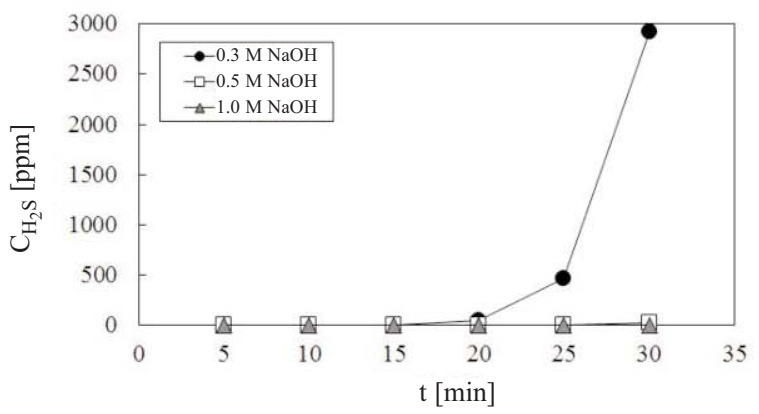

C)

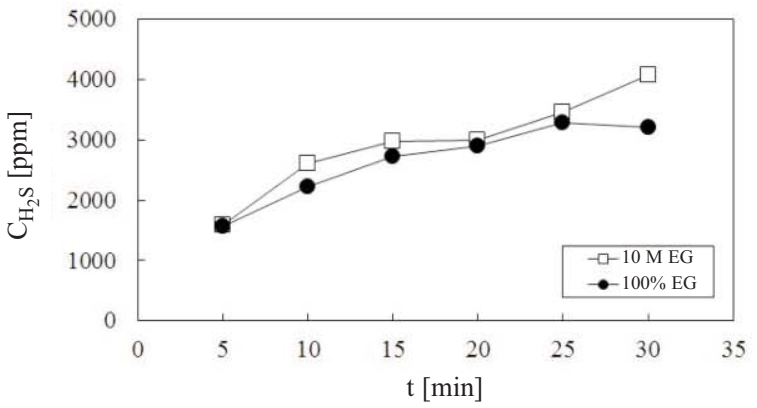

e)

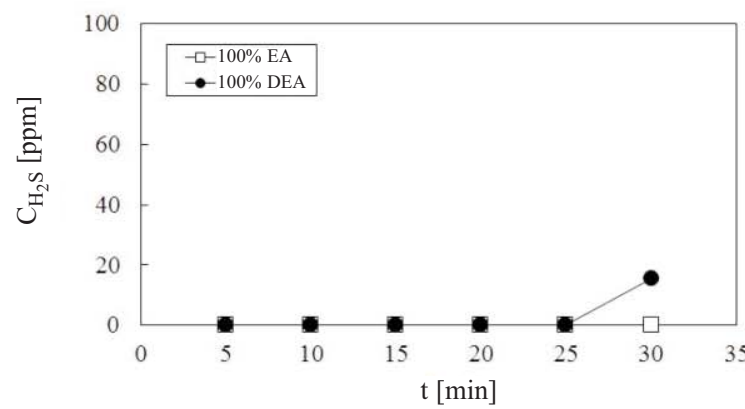

g)

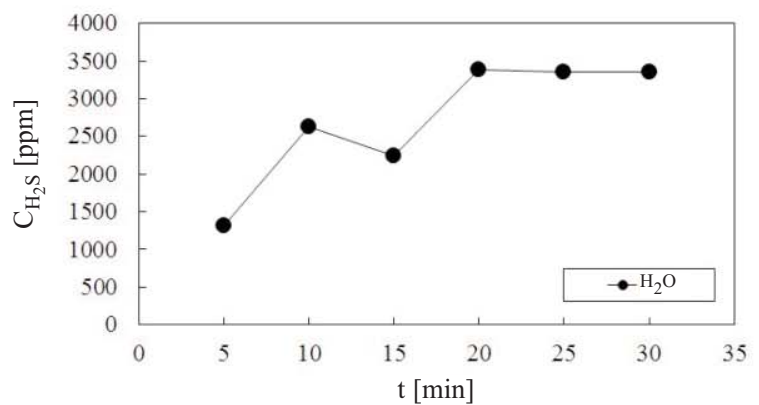

towards $\mathrm{CO}_{2}$. Higher concentrations of $\mathrm{CO}_{2}$ at the outlet of the adsorption column compared to its inlet value might be related to actual dynamic properties of the gas stream. $\mathrm{H}_{2} \mathrm{~S}$ concentration variations during the adsorption process showed a similar trend as observed during absorption by barbotage: low value at the beginning and increasing values with time (Fig. 5). $\mathrm{CO}_{2}$ concentration levels were rather stable throughout the experiments, with the exception of tests with $\mathrm{AC}$, which initially showed the ability to reduce $\mathrm{CO}_{2}$ concentration to about $20-45 \%$ of the original value, depending on bed height. The influence of bed height (reagent mass) was observed only in the case of $\mathrm{H}_{2} \mathrm{~S}$. For $\mathrm{BIO}$, the $\mathrm{H}_{2} \mathrm{~S}$ reduction rate was almost proportional to bed height, while for AC any similar relationship was not observed during test duration.

b)



d)



f)

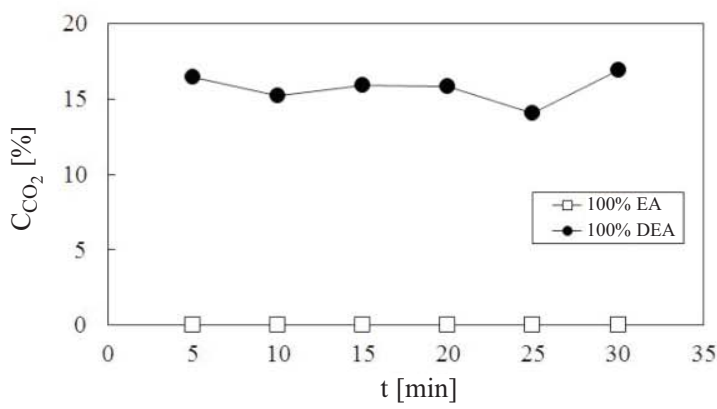

h)



Fig. 4. $\mathrm{H}_{2} \mathrm{~S}$ and $\mathrm{CO}_{2}$ concentrations in biogas treated with barbotage using $\mathrm{NaOH}(\mathrm{a}, \mathrm{b}), \mathrm{EG}(\mathrm{c}, \mathrm{d}), \mathrm{EA}$ and DEA (e, f), $\mathrm{H}_{2} \mathrm{O}(\mathrm{g}, \mathrm{h})$. 


\section{Discussion}

It should be noted that the experimental work presented in this paper is of mainly preliminary character and is aimed at demonstrating the functionality of the test stand and its ability to absorb $\mathrm{CO}_{2}$ and $\mathrm{H}_{2} \mathrm{~S}$ rather than examining its operation over a long period of time. It is, however, possible to generate $\mathrm{CH}_{4}$-enriched biogas for a prolonged period using a proper combination of both sections of the test stand, i.e. barbotage and bed adsorption column, and most of the tested reagents. Further work may be required to prove this possibility.

Another aspect to consider in the continuation of the present study should be the examination of a wider range of concentrations of reagents (or heights of adsorption column), with special attention paid to amines. Several different biogas flow rates should be taken into account and its influence on the process investigated. Finally, a scale-up of the biogas treatment process, with the most efficient reagents and optimum values of the process parameters, is needed to achieve a desirable level of efficiency.

The main problem of the test stand seems to be maintaining a high and stable absorption/adsorption rate of the reagents. Even though the process often started rapidly, resulting in low concentrations of $\mathrm{CO}_{2}$ and $\mathrm{H}_{2} \mathrm{~S}$, in most cases this state eventually changed and the concentrations increased. One of the ways to deal with this problem may be a simple increase of the reagents volume, according to the needs of the process. Another solution to consider is frequent recurring replacement of the reagent [13], but this would require interruption of the process or modification of the construction of the test stand sections.

Although amines have high $\mathrm{H}_{2} \mathrm{~S}$ - and $\mathrm{CO}_{2}$-absorbing efficiencies, their cost is relatively high. However, saturated reagents can be regenerated [14], and depending on the size of the application they could become economically more attractive than other absorbers [14]. Therefore, some limited attempts were made (but not yet published) to examine the regeneration of amines. The obtained results allow considering this as a promising step toward further research works involving setting up a regeneration system for amine absorbent and evaluation of its long-term performance.

Economic aspects of the biogas treatment process were not considered in the present work. Notwithstanding, the emphasis was on the low cost and simplicity of the construction of the test stand for laboratory use.

\section{Conclusions}

Biogas from waste and renewable resources appears to be a promising answer to the environmental and energy problems of the world, as it can be used for replacement of fossil fuels in heat and power generation as well as in transport [18]. The conversion of wastes into biogas is not only an effective way to recover energy from the waste, but also allows reduction of odors, increase of nutrient availability, and reduction of pathogen content $[19,20]$. Among the reasons why this conversion process has not yet become common is the poor quality of raw biogas and the high maintenance requirements of systems in which it is used $[12,14]$. Treating biogas by removing $\mathrm{H}_{2} \mathrm{~S}$ and $\mathrm{CO}_{2}$ would solve both of these issues.

The results obtained from the laboratory-scale biogas treatment carried out within this study confirmed the technical feasibility and effectiveness of the developed test stand. Both sections, i.e. absorption barbotage reactor and adsorption column, proved to be an effective technique for removing $\mathrm{H}_{2} \mathrm{~S}$ and $\mathrm{CO}_{2}$ if proper reagents are used. a)

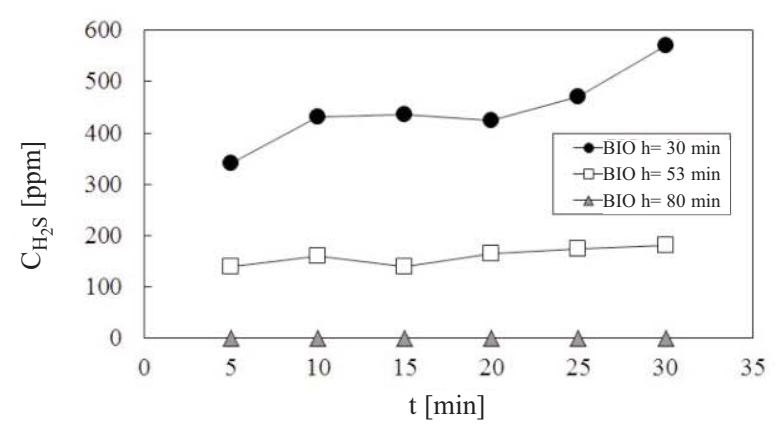

c)

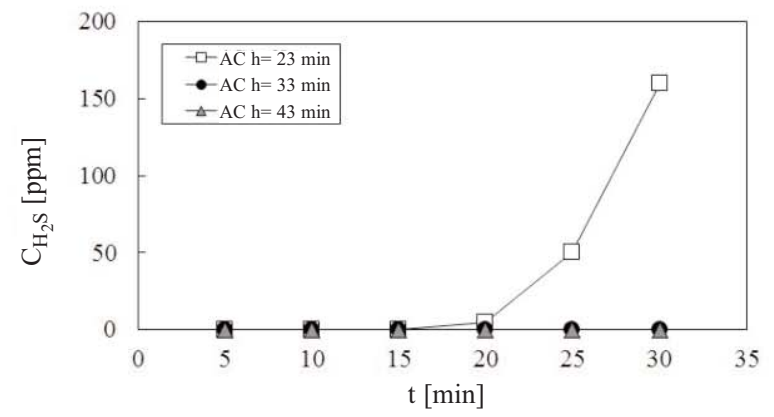

b)



d)

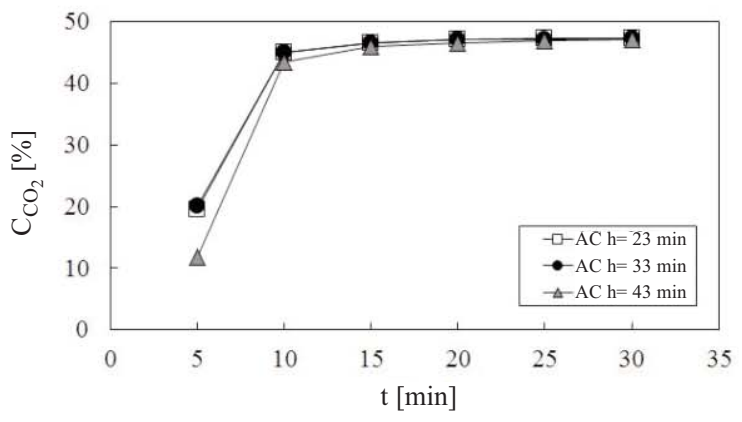

Fig. 5. $\mathrm{H}_{2} \mathrm{~S}$ and $\mathrm{CO}_{2}$ concentrations in biogas treated with adsorption in a bed of solid reagent: $\mathrm{BIO}(\mathrm{a}, \mathrm{b})$ and $\mathrm{AC}(\mathrm{c}, \mathrm{d})$ 
Aqueous solutions of $\mathrm{NaOH}, \mathrm{EA}, \mathrm{DEA}$, and EG, as well as $\mathrm{H}_{2} \mathrm{O}$, were used in the barbotage section of the test stand. In terms of practical application, the first three chemical compounds were suitable absorbents while the last two, by contrast, did not meet expectations.

The performance of the single-stage absorption tests using either $1 \mathrm{M} \mathrm{NaOH}$ solution or $100 \% \mathrm{EA}$, under specific experimental conditions, provided basically the same results: complete removal of $\mathrm{H}_{2} \mathrm{~S}$ and $\mathrm{CO}_{2}$. For $100 \%$ DEA, high $\mathrm{H}_{2} \mathrm{~S}$ and moderate $\mathrm{CO}_{2}$ absorption efficiency were achieved. EG and $\mathrm{H}_{2} \mathrm{O}$ allowed the removal of $\mathrm{H}_{2} \mathrm{~S}$ only to a very limited extent. Looking at the results obtained from the tests with adsorption in a column, it can be noted that both reagents, $\mathrm{BIO}$ and $\mathrm{AC}$, were able to eliminate $\mathrm{H}_{2} \mathrm{~S}$ from biogas, but practically did not change the concentration of $\mathrm{CO}_{2}$.

The main aims of the study appear to have been achieved as a simple, low-cost test stand for laboratory use was developed and its ability to upgrade biogas quality was successfully proven. Comprehensive assessment of the absorption or adsorption performance of the considered reagents, widely discussed in literature [13-15, 21-24], did not fall within the scope of this study. This context should be borne in mind when considering the presented test results.

Above all, absorption and adsorption trends for the reagents used in experiments may be worth exploring further due to their tendency to decline with time. A larger number of measurement points (more frequent concentration measurements) and statistical analysis should be included. Additional experimental results are required to provide the basis for test stand design optimization, as well as subsequent upscaling.

The next phase of experimental work could involve evaluation of the biogas cleaning effect obtainable with the use of different substances over a wider concentrations range, including microorganisms typical to biological methods of biogas treatment. It would also be advantageous to set up an integrated regeneration step for amine absorbent as well as to evaluate its long-term performance. Finally, cost analysis of the process, leading to an increase in its efficiency, could be performed.

\section{Acknowledgements}

This work has been supported by The National Centre for Research and Development (NCBiR) through research grant No. 5030E! BIOGASFUEL "Development and implementation of a dual fuel supply system for diesel engines supplied by an agriculture biogas and a diesel fuel dose."

\section{References}

1. CHU S., MAJUMDAR A. Opportunities and challenges for a sustainable energy future. Nature 7411, (488), 294, 2012.
2. RESCH G., HELD A., FABER T., PANZER C., TORO F. Potentials and prospects for renewable energies at global scale. Energ. Policy 36, 4048, 2008.

3. CRUZ C. H. B., SOUZA G. M., LUIZ A. CORTEZ B. Biofuels for Transport. In: LETCHER T. M. (Ed.) Future Energy. Elsevier: Boston, pp. 215-244, 2014.

4. OWCZUK M. Biodiesel and environmental protection. Chem. Rev. 88, (3), 240, 2009.

5. MENTEN F., CHËZE B., PATOUILLARD L., BOUVART F. A review of LCA greenhouse gas emissions results for advanced biofuels: The use of meta-regression analysis. Renew. Sust. Energ. Rev. 26, 108, 2013.

6. DE CASTRO C., CARPINTERO Ó., FRECHOSO F., MEDIAVILLA M., DE MIGUEL L. J. A top-down approach to assess physical and ecological limits of biofuels. Energy 64, (1), 506, 2014.

7. CHŁOPEK Z., LASOCKI J. Comprehensive environmental impact assessment of the process of preparation of bioethanol fuels of the first and second generation. Eksploatacja i Niezawodnosc - Maintenance and Reliability 15, (1), 44, 2013.

8. ZAH R., BÖNI H., GAUCH M., HISCHIER R, LEHMANN M., WÄGER P. Life cycle assessment of energy products: environmental assessment of biofuels. EMPA: St. Gallen 2007.

9. HANSEN C. L., CHEONG D. Y. Agricultural waste management in food processing. In: KUTZ M. (Ed.) Handbook of farm, dairy and food machinery engineering, $2^{\text {nd }}$ ed.; Elsevier, pp. 619-666, 2013.

10. BUSCH G., GROßMANN J., SIEBER M., BURKHARDT $\mathrm{M}$. A new and sound technology for biogas from solid waste and biomass. Water Air Soil Pollut.: Focus 9, (1-2), 89, 2009.

11. DINCER I. Renewable energy and sustainable development: a crucial review. Renew. Sust. Energ. Rev. 4, (2), 157, 2000.

12. RYCKEBOSCH E., DROUILLON M., VERVAEREN H. Techniques for transformation of biogas to biomethane. Biomass Bioenerg. 35, (5), 1633, 2011.

13. TIPPAYAWONG N., THANOMPONGCHART P. Biogas quality upgrade by simultaneous removal of $\mathrm{CO}_{2}$ and $\mathrm{H}_{2} \mathrm{~S}$ in a packed column reactor. Energy 35, (12), 4531, 2010.

14. HUERTAS J. I., GIRALDO N., IZQUIERDO S. Removal of $\mathrm{H}_{2} \mathrm{~S}$ and $\mathrm{CO}_{2}$ from biogas by amine absorption. In: MARKOŠ J. (Ed.) Mass transfer in chemical engineering processes. InTech, pp. 133-150, 2011.

15. DE HULLU J., MAASSEN J. I. W., VAN MEEL P. A., SHAZAD S., VAESSEN J. M. P., BINI L., REIJENGA J. C. Comparing different biogas upgrading techniques. Final report. Eindhoven University of Technology, 2008. http://students.chem.tue.nl/ifp24/BiogasPublic.pdf (Accessed 1.11.2014).

16. ANDRIANI D., WRESTA A. ATMAJA T. D. SAEPUDIN A. A review on optimization production and upgrading biogas through $\mathrm{CO}_{2}$ removal using various techniques. Appl. Biochem. Biotechnol. 172, 1909, 2014.

17. KRISCHAN J., MAKARUK A., HARASEK M. Design and scale-up of an oxidative scrubbing process for the selective removal of hydrogen sulfide from biogas. J. Hazard. Mater. 215-216, (15), 49, 2012.

18. DENG Y., XU J., LIU Y., MANCLY. Biogas as a sustainable energy source in China: Regional development strategy application and decision making. Renew. Sust. Energ. Rev. 35, 295, 2014.

19. GARRISON M., RICHARD T. Methane and manure: feasibility analysis of price and policy alternatives. T ASAE $\mathbf{4 8 ,}$ (3), 1287, 2005. 
20. GOODRICH P., SCHMIDT D., HAUBENSCHILD D. Anaerobic digestion for energy and pollution control. Agric. Eng. Int.: CIGR Ejournal VII, 2005.

21. AROONWILAS A., TONTIWACHWUTHIKUL P., CHAKMAA. Effects of operating and design parameters on $\mathrm{CO}_{2}$ absorption in columns with structured packings. Separ. Purif. Technol. 24, 403, 2001

22. GEORGIOU D., PETROLEKAS P. D., HATZIXANTHIS S., AIVASIDIS A. Absorption of carbon dioxide by raw and treated dye-bath effluents. J. Hazard. Mater. 144, 369 , 2007.

23. LIN S. H., SHYU C. T. Performance characteristics and modeling of carbon dioxide absorption by amines in a packed column. Waste Manage. 19, 255, 1999.

24. YEH J. T., RESNIK K.P., RYGLE K., PENNLINE H. W. Semi-batch absorption and regeneration studies for $\mathrm{CO}_{2}$ capture by aqueous ammonia. Fuel Process. Technol. 86, 1533, 2005. 